\title{
TITLE:
}

\section{A PALE BLUE CHAETOGNATH FROM TANABE BAY}

$\operatorname{AUTHOR}(S)$ :

Bieri, Robert

CITATION:

Bieri, Robert. A PALE BLUE CHAETOGNATH FROM TANABE BAY.

PUBLICATIONS OF THE SETO MARINE BIOLOGICAL LABORATORY 1966, 14(1): 21-22

ISSUE DATE:

1966-04-25

URL:

http://hdl.handle.net/2433/175424

RIGHT: 


\title{
A PALE BLUE CHAETOGNATH FROM TANABE BAY ${ }^{13}$
}

\author{
ROBERT BIERI \\ Antioch College, Yellow Springs, Ohio, U.S.A.
}

Most species of Chaetognatha are colorless except for the brown to black eye spots and in some species red-brown seminal vesicles. Nevertheless, there are several reports in the literature of colored chaetoghaths. The orange-red bathypelagic chaetognaths such as Eukrohnia fowleri, E. hamata, and Caecosagitta macrocephala are well known. In these species the gut is usually filled with an orange-red material containing many small oil droplets. Presumably the pigment is derived by the carnivorous chaetognaths from orange-red bathypelagic copepods on which they probably feed. Apparently there are no reports in the literature on the food of these species, but since the chief food item of the epipelagic chaetognaths is copepods, it seems reasonably safe to assume that this would be true for their deeper living relatives (Furnestin, 1959).

Benthic chaetognaths of the genus Spadella are yellowish-olive colored. In live specimens collected off San Diego, California, I observed some specimens with red in the posterior region, but due to the rather violent pitching of the ship at the time I was not able to see clearly just what structures had the color. It may have been the seminal vesicles as TокіокA (1939) has reported these organs are red-brown in live specimens of three planktonic species.

Germain and Joubin (1916) reported a green specimen of the pelagic chaetognath, Eukrohnia hamata. From the peculiar distribution of the pigment shown in their plate it appears that the color is an artifact possibly from a piece of copper wire put in the plankton jar with the label. AIDA (1897) reported faintly yellowish-green epidermis and ovaries in Krohnitta pacifica, apparently from his observations of living specimens as the preserved forms do not show this.

In a letter two years ago, Peter DAvid wrote me that with his neuston net he had caught a blue chaetognath from the surface of the Indian Ocean. Because I had observed hundreds of live chaetognaths from the surface waters off California and in the Mediterranean belonging to many different species and had never seen a blue chaetognath, I was quite surprised at his

1) Contributions from the Seto Marine Biological Laboratory, No. 450.

Publ. Seto Mar. Biol. Lab., XIV (1), 21-22, 1966. (Article 4) 
report. About six months ago he sent me a color slide of this specimen which is clearly a dark blue. It appeared to me as if it had been stained in indigo blue and $I$ asked him if someone on board ship could be playing a practical joke. DAvid indicated in a more recent letter that he thought this was not so, but that the specimen might have become blue from being near a specimen of Ianthina.

After expressing some skepticism, I was indeed chagrined but excited to find a very pale blue chaetognath alive in a sample of water collected at a depth of $20 \mathrm{~cm}$ in water one meter deep in Tanabe Bay just north of the Seto Marine Biological Laboratory. I observed this specimen in the water while looking at the neuston and hyponeuston with a face mask and was able to catch it in a plastic bottle. To make sure that my eyes were not deceiving me, I asked my daughter to check the bottle for a blue chaetognath and she was able to point it out in a few seconds. We isolated the specimen and preserved it in dilute formalin. Twenty-four hours later it had lost its color and turned milky white. Takasi Tokıoka and I identified it as Serratosagitta pacifica.

In this case the digestive tract was not particularly blue, in fact in the live animal we could not distinguish the digestive tract with the unaided eye. The color was quite faint but distinct. It could be due to the absorption of blue pigment after eating some surface dwelling pontellid copepods or it could be a structural color due to the scattering of blue light by fine particles within the body. There is an oil droplet in the digestive tract just above the ventral ganglion. At the present time I lean towards the idea that the blue color is a rather rare phenomenon due to the eating of blue colored copepods. If this is the case, then we can expect to find from time to time several of the species that occur at the surface colored various shades of blue.

\section{REFERENCES}

AIDA, T. 1897. Chaetognaths of Misaki Harbor. Annot. Zool. Jap., Vol. I, pp. 13-21.

Furnestin, M.-L. 1959. Sur la coloration du tube digestif de certains chaetognathes. Bull. Soc. Zool. France, Tom. 84, pp. 132-135.

Germain, L. and L. Joubin. 1916. Chétognathes provenant des Campagnes de la Princesse Alice. Résultats Camp. Scient. Monaco, No. 49.

ToKIoKA, T. 1939. Chaetognaths collected chiefly from the bays of Sagami and Suruga, with some notes on the shape and structure of the seminal vesicle. Rec. Oceanogr. Works Jap., Vol. 10, pp. 123-150. 